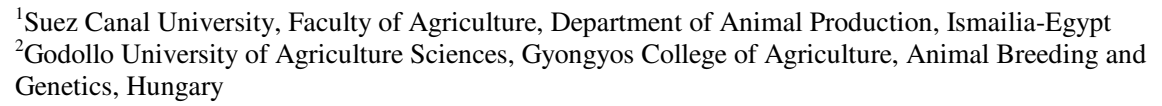

ASHRAF A. AMIN ${ }^{1}$, TIBOR GERE ${ }^{2}$ and WALID H. KISHK ${ }^{1}$

\title{
Genetic and environmental relationship among udder conformation traits and mastitis incidence in Holstein Friesian into two different environments
}

\begin{abstract}
Summary
Type-performance of udder of Holstein-Friesian was analyzed using multi-trait animal model in two different environments (Hungary and Egypt). Udder traits were: udder height and depth. Teat traits were teat length, attachment and placement. Multi-trait animal model was used to compute estimates of additive variance and covariance components. 2507 records of 549 cows and 6011 records of 2018 cows were collected from Egypt and Hungary respectively. Heritability estimates of udder and teat characteristics ranged from 0.35 to 0.45 and from 0.32 to 0.59 in Hungarian and Egyptian cows, respectively. Heritability estimates of udder traits in both environments were higher than the corresponding estimates for teat traits. Udder characteristics of Egyptian Holstein-Friesian (EHF) had inheritance power higher than for Hungarian Holstein-Friesian (HHF). Mastitis was moderately correlated with udder height and teat traits in each environment. Additive genetic variance and heritability of the most studied traits increased with the advancing order of lactation in each environment. Heritabilities of mastitis were low. Sire and dam variance components of all studied traits were higher in EHF than HHF herds. Mastitis was strongly correlated negatively with udder depth of EHF than HHF. The genetic analysis results of the present study, indicate that udder characteristics should be taken into consideration during planning of selection strategies for improving dairy cattle performance. Enhancing management levels of Egyptian environmental conditions is very essential for improving general performance of the most exotic dairy cattle breeds. EHF has great chances for genetic improvement to mastitis resistance through selection, based on udder descriptive performance.
\end{abstract}

Key Words: Holstein Friesian, Hungary, Egypt, udder traits, mastitis, genetic and phenotypic correlation, environment, heritability

\section{Zusammenfassung}

Titel der Arbeit: Genetische und Umweltbeziehungen zwischen Eutermerkmalen und Mastitis untersucht an Holstein-Friesian Rindern in unterschiedlichen Umwelten

Eutermerkmale von Holstein-Friesian Kühen aus Ägypten und Ungarn wurden mittels eines MehrmerkmalTiermodells zur Schätzung genetischer Parameter genutzt. Einbezogen waren die Merkmale Euterlänge und höhe, Zitzenlänge, Zitzenaufhängung und Zitzenverteilung. Daten von 2500 Laktationsabschlüssen von 549 Kühen aus Ägypten und 6011 Abschlüssen von 2018 Kühen aus Ungarn konnten genutzt werden. In beiden Umwelten lagen die Heritabilitätsschätzwerte für Eutermerkmale höher als für Zitzenmerkmale. In beiden Umwelten waren die Eutertiefe und die Zitzenmerkmale mäßig korreliert mit dem Auftreten von Mastitis. Die additive genetische Varianz und die Heritabilitätsschätzwerte der meisten untersuchten Merkmale erhöhten sich mit steigender Laktationsnummer in beiden Umwelten. Die $\mathrm{h}^{2}$-Schätzwerte für Mastitis waren relativ niedrig. In beiden Umwelten war die Mastitis eng negativ korreliert mit der Eutertiefe, bei den ägyptischen Kühen mehr als bei den ungarischen. Die Ergebnisse zeigen, dass Eutermerkmale bei der Planung von Selektionsstrategien unbedingt berücksichtigt werden sollten. Die Ergebnisse in Ägypten können sowohl hinsichtlich vergleichbarem Management als auch der Umweltbedingungen für viele exotische Milchrindrassen als Beispiel gelten.

Schlüsselwörter: Holstein Friesian, Ungarn, Ägypten, Eutermerkmale, Mastitis, genetische und phänotypische Korrelation, Umwelt, Heritabilität 


\section{Introduction}

Possibilities of improving mastitis resistance by indirect selection of udder and teat conformation traits seem to be an appropriate method for different environments. Estimates of genetic parameters of dairy cattle performance were investigated in different countries using different statistical methods for the same climatic conditions. Most subtropical countries import a large part of their dairy cattle herds from northern frosty countries. The young imported individuals should be reared under suitable temperature and sufficient feed for optimum physiological functions. Usually they are managed under inappropriate climate conditions. Therefore, change of the genetic performance due to the previous circumstances has not been obvious yet. Therefore evaluation of the individual breeding value and effect of drought on the performance of dairy cattle is extremely needed. THOMAS et al. (1984) in the USA concluded that selection against deep udders, especially low rear udder widely placed teats, rear teats too far back, and teats that are short and wide might help reducing incidence of mastitis in a mastitis control program. Estimates of heritability $\left(h^{2}\right)$ of udder deeps and attachment were ranged from 0.09 to 0.14 (MONARDES et al., 1989). Association of some teat and udder morphological characteristics with mastitis incidence (BAKKEN, 1981; VAN VLECK and HORMAN, 1972) have been studied in different USA states and European countries of comparable environmental conditions. Computations of

genetic parameters in the Middle East as a semi drought region showed that $h^{2}$ for mastitis was 0.10 , genetic and phenotypic correlations of mastitis with milk were 0.22 , 0.66 and with fat were -0.032 , -0.025, respectively (WELLER et al., 1992). SEYKORA and McDANIEL (1986) found that $h^{2}$ of udder attachment and teat position ranged from 0.1 to 0.56 and 0.33 to .48 for $\mathrm{HF}$, reared in North Carolina. Udder morphologic traits with those influencing somatic cell count are to be taken into account in the selection work having the aim of decreasing somatic cell counts. In practice this implies boarding of formal breeding goals including both, yield traits and functional traits (BRASCAMP et al., 2000; BAUMUNG et al., 2000; GULYAS and IVANCSICS, 2001).

The objectives of the present study are i) to determine changing rate of genetic and phenotypic variance components of udder traits under deferent environmental conditions, ii) explain the role of environmental effects on rates of mastitis incidence.

\section{Materials and Methods}

Structure of the data: A total of 2567 Holstein-Friesian (HF) cows were reared and managed for production under conditions of two different climates. Rainy weather and opened housing system or grazing yard in Hungary and drought weather with closed or shadow yard system in Egypt. A total number of 8518 complete records were used in the present study. 2507 records of 549 cows and 6011 records of 2018 cows from Egypt and Hungary respectively. Data of Hungarian HF (HHF) involved the first three parities were collected from four farms. The data of HF in Egypt (EHF) involved five parities collected from three farms located in Salheia farms approximately $100 \mathrm{Km}$ east of Cairo. The investigated traits contained udder traits and rate of mastitis incidence. Mastitis defined using California Test for EHF and using somatic cell Examination for HHF. Udder traits involved udder depth (UD) and height (UH), teat length (TL), attachment (TA) and placement (TP). Udder traits for HHF were 
measured by Hungarian of Animal Breeding Association one time per year, usually in summer. Udder traits for EHF were measured using video camera. Four sides (front, back, left and right side) were captured for each individual animal. Through reviewing and using video still capture option we measured different studied udder traits. Two data sets were used for the statistical analysis of variance using two different statistical models. The first data set of Hungarian HF population included 82 paternal half-sib families and involved 20-32 cows per sire (model I), whereas, the second data set of $\mathrm{HF}$ in Egypt included 69 paternal half-sib families and involved 4-9 cows per sire (model II). Identification of all individuals in the $1^{\text {st }}$ data set was known as sire and dam, but only sire was known as regard the $2^{\text {nd }}$ data set. The natural $\log$ transformation was adapted to udder traits and mastitis score for the analysis of variance.

Statistical Analysis: Multitrait REML Animal Model was used for the statistical analysis of variance to generate estimates of genetic and phenotypic variances and covariances for all studied traits using MTDF-REML - package that was developed by BOLDMAN et al. (1997). Two mathematical models were considered for analysis of variance as follow: -

$$
\begin{gathered}
Y_{i j k l m}=\mu+S_{i}+H_{j}+P_{k}+D_{l i}+\varepsilon_{i j k l m \ldots \ldots \ldots \ldots \ldots(I)} \\
Y_{i j k l}=\mu+S_{i}+H_{j}+P_{k}+\varepsilon_{i j k l} \ldots \ldots \ldots \ldots \ldots . .(I I)
\end{gathered}
$$

$Y_{i j k l m}$ : natural log-transformation of udder traits, mastitis, $u$ : the population mean, $S_{i}$ : the random effect of the ith sire, $H_{j}$ : the fixed effect of $\mathrm{j}$ th herd (farm, year and season of calving in Egypt and + the district in Hungary), $P_{k}$ : the fixed effect of kth parity, $D_{l i}$ : the random effect of 1 th dam within ith sire (model I), and $e_{i j k l(m)}$ : the random residual.

\section{Results and Discussion}

Estimates of sire and random error variance component of udder characteristic and mastitis are presented in Table 1. The absolute estimates of sire and error variance component of udder descriptive traits were higher in EHF (model II) than HHF (model I). Since, elements of total phenotypic variance for HHF were sire, dam, and error variance component mean while for EHF elements were only sire and error variance component.

Table 1

Sire $\left(\sigma^{2}\right)$ and residual $\left(\sigma_{e}^{2}\right)$ variances for udder descriptive traits and mastitis for Hungarian (HHF) and Egyptian

\begin{tabular}{|c|c|c|c|c|c|c|}
\hline & \multicolumn{2}{|c|}{$H H F$} & \multirow{2}{*}{$\frac{\text { Model I }}{\sigma_{e}^{2}}$} & \multicolumn{2}{|c|}{$E H F$} & \multirow{2}{*}{$\frac{\text { Model II }}{\sigma_{e}^{2}}$} \\
\hline & Sire & $\sigma_{S}^{2}$ & & Sire & $\sigma_{S}^{2}$ & \\
\hline Udder Depth: UD & $* * *$ & 46.69 & 36.69 & $* * *$ & 69.17 & 473.34 \\
\hline Udder Height: UH & $* * *$ & 63.05 & 32.94 & $*$ & 86.13 & 497.80 \\
\hline Teat Placement: TP & $* *$ & 83.10 & 61.18 & $*$ & 122.47 & 877.29 \\
\hline Teat Length: TL & $*$ & 53.18 & 43.30 & $* * *$ & 134.19 & 1543.19 \\
\hline Teat Attachment: TA & $* *$ & 69.11 & 51.71 & $* *$ & 94.28 & 675.35 \\
\hline Mastitis: Mas & $*$ & 0.01 & 0.23 & $* *$ & 0.07 & 2.03 \\
\hline
\end{tabular}
Holstein-Friesian (EHF).

***, **, * significance at $\mathrm{P}<0.001, \mathrm{P}<0.01$ and $\mathrm{P}<0.05$, respectively

The amount of additive variance of all udder descriptive traits of EHF was smaller than the corresponding estimate in Hungarian one. In contrast, absolute estimates of 
sire variance component of mastitis within rainy conditions for HHF were higher and more significant than the corresponding estimates within subtropical area for EHF.

Heritability: Estimates of genetic parameters for teat and udder traits that computed for each of HHF and EHF data sets are presented in Table 2. In general, heritability of udder descriptive traits was not low and ranged from 0.35 to 0.45 and 0.32 to 0.41 for EHF and HHF, respectively. Heritability of udder traits was higher than teat traits within each environment. All descriptive udder traits of EHF were higher in their magnitude than the contrary one of HHF except that for teat length. Maximum difference between heritabilities of udder traits of $\mathrm{HHF}$ was $50 \%$ lower than that of corresponding one in the other environment. This shows extremely the differences in genetic expression of Holstein-Friesian between the two different environments.

Table 2

Genetic parameters generated by using separate analysis for Egypt and Hungary data -sets.

\begin{tabular}{|c|c|c|c|c|c|c|}
\hline & \multicolumn{3}{|c|}{$H H F$} & \multicolumn{3}{|c|}{$E H F$} \\
\hline & $h^{2}$ & $r_{g}$ & $r_{p}$ & $h^{2}$ & $r_{g}$ & $r_{p}$ \\
\hline Udder Depth: UD & $.45 \pm .13$ & $-.43 \pm .16$ & $-.23 \pm .09$ & $.51 \pm .21$ & $-.67 \pm .11$ & $-.87+.12$ \\
\hline Udder Height: UH & $.42 \pm .11$ & $.51 \pm .17$ & $.43 \pm .18$ & $.59 \pm .32$ & $.39 \pm .21$ & $.37 \pm .11$ \\
\hline Teat Placement: TP & $.35 \pm .11$ & $.22 \pm .01$ & $.17 \pm .07$ & $.49 \pm .11$ & $.23 \pm .11$ & $.29 \pm .13$ \\
\hline Teat Length: TL & $.37 \pm .09$ & $.24 \pm .12$ & $.28 \pm .11$ & $.32 \pm .09$ & $.44 \pm .09$ & $.65 \pm .17$ \\
\hline Teat Attachment: TA & $.35 \pm .12$ & $.32 \pm .09$ & $.42 \pm .11$ & $.49 \pm .13$ & $.45 \pm .19$ & $.57 \pm .12$ \\
\hline Mastitis: Mas & $.09 \pm .13$ & $1.00 \pm .00$ & $1.00 \pm .00$ & $.13+.03$ & $1.00 \pm .00$ & $1.00 \pm .00$ \\
\hline
\end{tabular}

$h^{2}$ : heritability, $r_{g} \& r_{p}$ : genetic and phenotypic correlation with mastitis

The current results indicate that teat and udder traits are very high heritable when measured accurately. Improvement total net dairy cattle income through selection based on udder and teat measurements should be effective under both environmental conditions. EHF had higher possibilities than HHF for improving mastitis resistance through indirect selection using udder descriptive traits.

Heritability estimates of descriptive udder traits agreed greatly with those reported by SCHAEFFER (1983) and BOETTCHER et al. (1998). Some estimates of heritability herein were in close agreement with those reported for US Holstein in different state with different climate conditions (SCHAEFFER et al., 1985; SMITH et al. 1985; THOMPSON et al., 1981; THOMPSON et al., 1983). MONARDES et al. (1989) reported that, different scoring systems, different population, sampling size, and different definitions of each trait must be considered when making comparisons. However, population size is one of the main item that is quite different between two population studied.

Low heritability estimates of mastitis were obtained within both conditions. Although heritability of mastitis for EHF was higher by at least $40 \%$ than the corresponding estimate for HHF. This may indicate that HHF population is more homogeneous with low sire variance component than EHF for mastitis infection rates. This may be due to early voluntary and involuntary culling of the mastitic cows in Hungarian herds. Hungarian dairy farms applying similar management programs, and therefore variation in the most dairy cattle traits due to farm effect were very little (AMIN et al., 1996, AMIN, 1998, AMIN et al., 2000). This is may be the important reason for reducing amount of total phenotypic variance for mastitis. On the other hand increasing amount of sire variance component for mastitis in EHF could help us for achieving some genetic improvement for mastitis resistance. 
On the contrary, from a practical point of view, genetic analysis for mastitis incidence in the both herds may indicates that direct genetic selection will not be effective in reducing incidence rate of mastitis in addition this tool will be very costing and time consuming. Therefore direct improvement of environmental condition cloud play an important role in improving individual mastitis resistance.
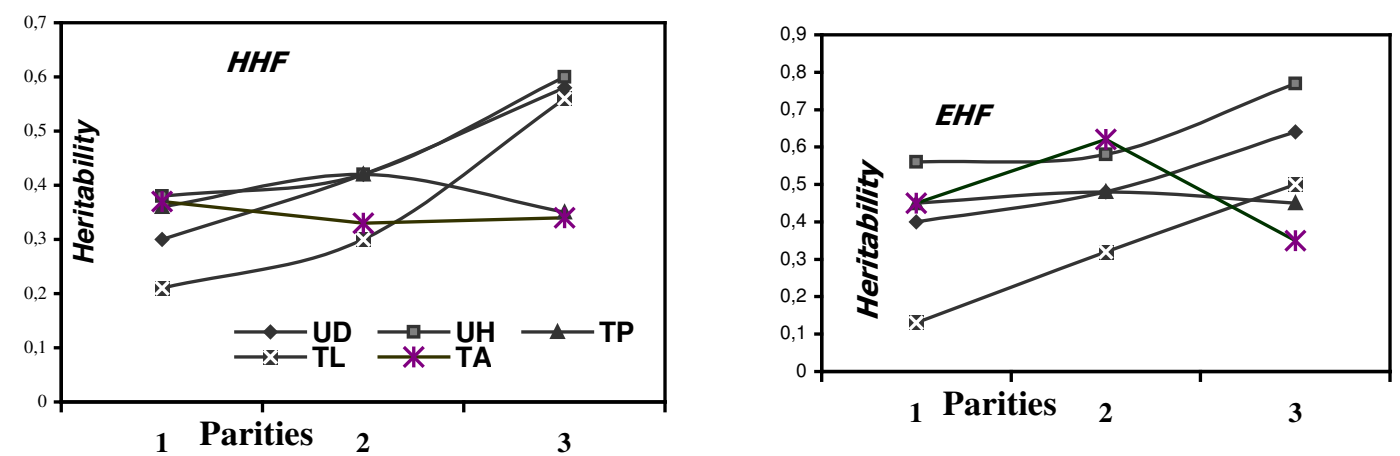

Fig. 1: Estimates of heritability for udder traits of the first three parities for Egyptian (EHF) and Hungarian Holstein-Friesian (HHF)

Heritability estimates of udder and teat conformations of the first three parities of HHF and EHF are shown in Figure 1. The current results for HHF in the first parity are in agreement with that reported by (WEIGEL et al., 1997; SCHUTZ and VANRADEN, 1993). Results in Figure 1 show that differences among heritability of udder traits of HHF were narrow compared with estimates for EHF. This may indicates that, all udder traits of HHF can play a similar role in selection index if each was considered for indirect improvement of mastitis resistance. Heritability estimates of udder traits for EHF increased with advancing order of lactation except for teat attachment in the $3^{\text {rd }}$ parity. Obvious ascending trend of $h^{2}$ for teat attachment and a descending trend for $h^{2}$ of teat length was obtained for HHF. On the other hand, $h^{2}$ of teat length increased rapidly from the $1^{\text {st }}$ to the $3^{\text {rd }}$ parity for EHF compared with the corresponding estimates for EHF. These results are in agreement with reports of SEYKORA and McDANIEL (1986). These data may indicate different genetic background in different lactations and/or some sort of genetic by environment interaction. This also may indicate that selection strategies for a specific trait(s) that are convenient in some locations may not be appropriate for the others.

Results in Figure 2 show that estimates of heritability of mastitis of HHF had a moderate change across parities. On the other hand heritability estimates for mastitis of EHF increased progressively from the $1^{\text {st }}$ parity to the $3^{\text {rd }}$ parity. This may indicate to genetic expression for mastitis incidences are more developmental with advancing order of lactation for EHF. Heritability estimate of mastitis of EHF increased about $30 \%$ approximately with advancing order of lactation. Results in Figure 2 show that heritability of mastitis for HHF and EHF in the $1^{\text {st }}$ parity were similar. This may indicate that environmental-genetic interaction in mastitis could be not significantly in early lactations. In the $3^{\text {rd }}$ parity estimates of heritability for mastitis increased by $50 \%$ for EHF than HHF. Results of heritability for mastitis are slightly higher than that reported by MILLER and SCHULTZE (1981) and THOMAS et al. (1984). While results for HHF agreement with EMANUELSON et al. (1988). In general, the current results indicate that the environmental condition play an important role in prevailing 
the most genetic variation in mastitis resistance. Hence, enhancing environment (good management health, good feeding program, cold weather, ... etc) could reduce rate of mastitis incidence. Therefore, it is not necessary of non-mastitic individuals of HHF having genetic factors for mastitis resistance. On the other hand, in the hot climate and drought weather (insufficient quality and quantity feeding, health caring isn't enough.... etc) may help for appearing the most inheritance cases of mastitis. Therefore the genetic variation in mastitis for EHF is higher than for HHF.

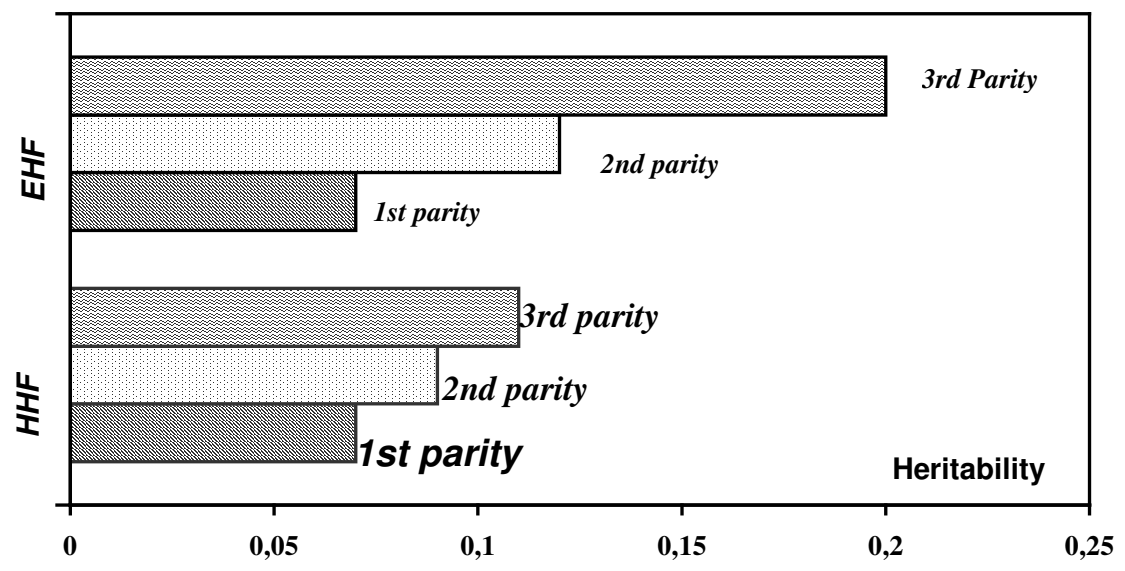

Fig. 2: Heritability estimates for mastitis in the first three parities in the both environments

Correlations with Mastitis: Values of genetic and phenotypic correlations between mastitis and each of descriptive udder traits are presented in Table 2. In general values are moderate medium to high. The current results are slightly higher than that reported by (EMANUELSON et al., 1988; EMANUELSON and PHILIPSON, 1984) but lower than that reported by (WEIGEL et al., 1977). Genetic correlations of udder traits with mastitis in both environments are above or equal to 0.40. All genetic correlations of udder traits with mastitis within subtropical condition for animals of EHF were very high than the corresponding estimates within rainy condition for animals of HHF, except that for udder height. In both environments udder depth was genetically negative correlated with mastitis. These coefficients either genetic or phenotypic of EHF were higher than that for HHF. This may be due to increasing frequency of mastitis incidence and high frequency of abnormal udder length in subtropical for EHF than in the rainy area for HHF. In addition growing rates of mastitis bacteria and distribution or infection rate may be faster through the subtropical climate.

Genetic $\left(r_{g}\right)$ and phenotypic $\left(r_{p}\right)$ correlations between teat traits and mastitis were positive and ranged from $r_{p}: 0.17$ to 0.57 and $r_{g}: 0.22$ to 0.45 . The current results are generally agree quite well with SEYKORA, (1982) and SEYKORA and McDANIEL (1986), GULYAS and IVANCSICS (2001). In both environments $r_{p}$ are higher than that $r_{g}$ except for teat placement. Mastitis was very closer with TL for EHF than for HHF. This indicates that EHF udders with long teat are mostly easy for infection than HHF. Phenotypic correlation was very high for EHF and reached 0.65 for TL. Selection for the highly heritable udder traits (udder depth and/or udder height) should lead to more mastitis resistance consequently.

Genetic $\left(r_{g}\right)$ and phenotypic $\left(r_{p}\right)$ correlations between udder and teat traits with mastitis in the first three parities for $\mathrm{EHF}$ and $\mathrm{HHF}$ are presented in Figure 3. In both environment teat length (TL) was negatively associated with mastitis. Most of these 
relationships either $r_{g}$ or $r_{p}$ were increased with advancing order of lactation. Estimates of $r_{g}$ were higher than $r_{p}$ for HHF in all parities, while the corresponding estimates for EHF fluctuated from parity to anther. Variations among estimates of $r_{p}$ between udder traits and mastitis of different parities in both environments were higher than the corresponding estimates of $r_{g}$. On the other hand variation among $r_{g}$ for HHF was little higher than for EHF in different parities. These results may support the previous suggestion of the considerable role of indirect selection for improving mastitis resistance using udder descriptive traits.
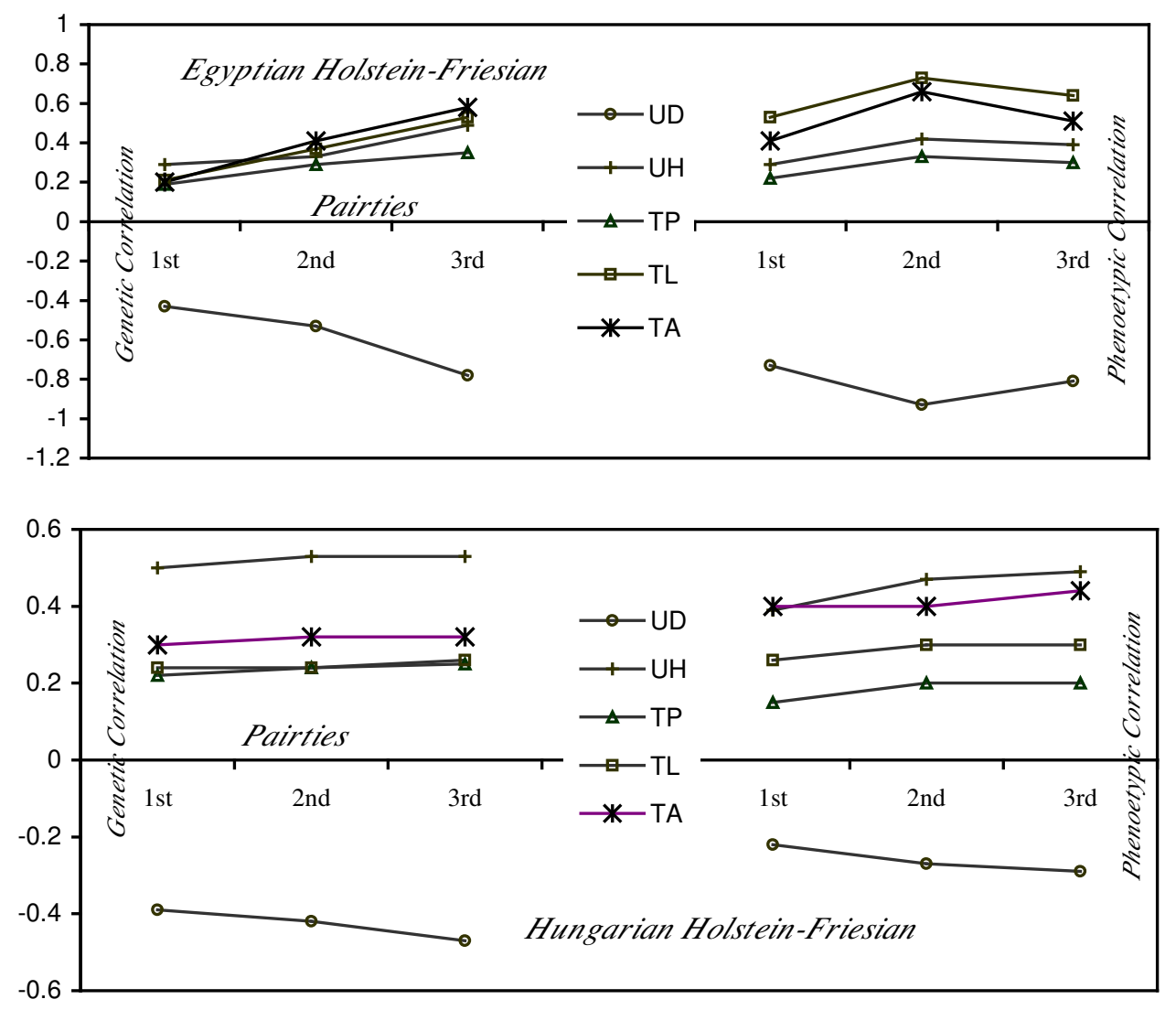

Fig. 3: Genetic and phenotypic correlations among udder descriptive traits and mastitis for Hungarian and Egyptian Holstein-Friesian

Table 3

Genetic correlations $r_{g}$ between the first three $\left(1^{\text {st }}, 2^{\text {nd }}, 3^{\text {rd }}\right)$ parities for all studied traits

\begin{tabular}{|c|c|c|c|c|c|c|}
\hline \multicolumn{4}{|c|}{ HHF } & \multicolumn{3}{|c|}{$E H F$} \\
\hline$R_{g}$ & $1^{s t} \& 2^{n d}$ & $1^{s t} \& 3^{r d}$ & $2^{\text {nd }} \& 3^{r d}$ & $1^{s t} \& 2^{n d}$ & $1^{s t} \& 3^{r d}$ & $2^{n d} \& 3^{r a}$ \\
\hline$\overline{\mathrm{UD}}$ & $.73 \pm .11$ & $.61 \pm .18$ & $.63 \pm .12$ & $.42 \pm .14$ & $.47 \pm .11$ & $.41 \pm .18$ \\
\hline UH & $.69 \pm .13$ & $.75 \pm .17$ & $.62 \pm .09$ & $.38 \pm .11$ & $.41 \pm .09$ & $.45 \pm .11$ \\
\hline $\mathrm{TP}$ & $.85 \pm .19$ & $.81 \pm .14$ & $.79 \pm \underline{ \pm} .17$ & $.83 \pm .21$ & $.83 \pm .19$ & $.82 \pm .17$ \\
\hline $\mathrm{TL}$ & $.86 \pm .32$ & $.65 \pm .18$ & $.62 \pm .11$ & $.52 \pm 20$ & $.67 \pm .24$ & $.69 \pm .24$ \\
\hline TA & $.87 \pm .40$ & $.79 \pm .32$ & $.82 \pm .28$ & $.42 \pm .09$ & $.52 \pm .11$ & $.50 \pm .18$ \\
\hline Mas & $.11 \pm .10$ & $.09 \pm .10$ & $.09 \pm .11$ & $.22 \pm .10$ & $.27 \pm .11$ & $.11 \pm .09$ \\
\hline
\end{tabular}

Genetic correlation for teat attachment (TA) and teat length (TL) with mastitis was of greatest magnitude for EHF. On the other hand, both $r_{g}$ and $r_{p}$ estimates of TL with mastitis were the greatest magnitudes for HHF. All genetic correlations in the $1^{\text {st }}$ parity for EHF except udder depth (UD) were smaller and similar in magnitude than that of phenotypic correlations, suggesting that environmental correlations were 
possibly positive and in considerable value. Therefore, the environmental conditions may play an important role in appearing the powerness of the genetic and phenotypic relationships among udder descriptive traits and mastitis incidence.

Genetic correlations between parities: Genetic correlation coefficients among the first three parities of the same trait are presented in Table 3. These correlations reflect the developing mechanism of the genetic makeup with advancing order of lactation. Estimation of these measures in the different two climate conditions explain the role of environmental effect on changing the interactions between genetic makeup mechanism and the performance of the same traits from parity to another. Results resented in Table 3 show that all correlation coefficients of udder and teat descriptive traits within rainy area were higher than the corresponding estimates within subtropical conditions except $\left(r_{\mathrm{g} 1,3}-r_{\mathrm{g} 2,3}\right.$ for teat placement and length. This may indicate that under drought conditions advancing order of lactation causes unfavorable effect on developing and increasing the power of genetic makeup efficiency for some udder traits. This is could be the reason of weakness the relationship between the performance of the same trait within subtropical conditions than within rainy conditions. Estimates of genetic correlation between parities for udder traits in the present study were less than that reported by BANOS and SHOOK (1990). These differences may be due to using different statistical methods, mathematical models and populations and sampling size. MAIJALA and HANNA (1974) reported that low estimates of genetic correlations for teat length between $1^{\text {st }}$ and later parities indicate that teat length may be considered a somewhat different trait in later parities than in the first. Estimates of genetic correlations between parities for udder depth and height did agree with the pervious conclusion because of the light relationships obtained between different parities especially within rainy area. On the other hand, estimates of genetic correlation for mastitis among parities for EHF were higher than for HHF. This may indicate that the inheritance factors may play an important role for continuing mastitis incidence across parities. Low genetic correlations for mastitis among parities especially for HHF may indicate that mastitic cows in early parities has low genetic ability for acquiring the same disease in the subsequent lactations. In other words, infected HHF cows in early lactations have a good genetic possibility of better udder health in subsequent lactations than for EHF decreased cows. This may mean also that different groups of gene were acting in different lactations, which in turn are responsible for different susceptibility for this disease. Under subtropical-condition genetic correlation between parities for mastitis was higher. This might indicate a greater number of genes that share the influence on mastitis in subsequent lactations. BANOS and SHOOK (1990) reported that reducing genetic correlation for milk production and mastitis between $1^{\text {st }}$ and $2^{\text {nd }}$ parity, may be due to culling in the $1^{\text {st }}$ parity that reduces correlations between sire evaluations.

\section{Conclusion}

The current results indicate that teat and udder traits are very high heritable when measured accurately. Improvement total net dairy cattle income through selection based on udder and teat measurements should be effective under both environmental conditions. EHF had higher possibilities than HHF for improving mastitis resistance through indirect selection using udder descriptive traits. Low heritability estimates of 
mastitis were obtained within both conditions. Although heritability of mastitis for EHF was higher by at least $40 \%$ than the corresponding estimate for HHF. Genetic analysis for mastitis incidence in the both herds may indicates that direct genetic selection will not be effective in reducing incidence rate of mastitis in addition this tool will be very costing and time consuming. Therefore direct improvement of environmental condition cloud play an important role in improving individual mastitis resistance. In both environments udder depth was genetically negative correlated with mastitis. These coefficients either genetic or phenotypic of EHF were higher than that for HHF. This may be due to increasing frequency of mastitis incidence and high frequency of abnormal udder length in subtropical for EHF than in the rainy area for HHF. Correlation among parities of udder and teat descriptive traits within rainy area were higher than the corresponding estimates within subtropical conditions except $\left(r_{\mathrm{g} 1,3}-r_{\mathrm{g} 2,3}\right)$ for teat placement and length. This may indicate that under drought conditions advancing order of lactation causes unfavorable effect on developing and increasing the power of genetic makeup efficiency for some udder traits.

AMIN, A.A.:

\section{References}

A selection indices for improving some productive and reproductive traits in dairy cattle. Ph.D. Desertion, Department of Animal Breeding and Genetics, University of Agriculture Sciences, Gödöllö, Hungary. 1998

AMIN, A.; TÓTH, S.; GERE, T.:

Selection indices for improvement milk and fat yield based on age at first mating and calving under Hungarian conditions. Arch. Tierz., Dummerstorf 39 (1996) 1, 25-32

AMIN, A.A.; GERE, T.; KISHK, W.H.:

Additive genetic variance and covariance in some reproductive disorders in Hungarian Holstein Friesian using multi-trait animal model Arch. Tierz., Dummerstorf 43 (2000), 573-581

BAKKEN, G.:

Relationships between udder and teat morphology, mastitis and milk production in Norwegian Red Cattle. Acta Agric. Scand. 31 (1981), 438-446

BANOS, G.; SHOOK, G.E.:

Genotype by environment interaction and genetic correlations among parities for somatic cell count and milk yield. J. Dairy Sci. 73 (1990), 2563-2573

BAUMUNG, R.; SÖLKNER, J.; GIERZINGER, E.; WILLAM, A.:

Ecological total merit index for an Austrian dual purpose cattle breed. Arch. Tierz., Dummerstorf 44 (2001), 5-13

BOETTCHER, P.J.; DEKKERS, J.C.M.; KOLSTAD, B.W.:

Development of an udder helth index for sire selection based on somatic cell score, udder conformation and milking speed. J. Dairy Sci., 81 (1998), 1157-1168

BOLDMAN, K.G., KRIESE, L.A.; VAN VLECK, L.D.; VAN TASSELL, C.P.; KACHMAN, S.D.:

A manual for use of MTDFREML. A set of programs to obtain estimates of variance and covariances,. US Department of Agric., Agric. Res. Service. 1997

BRASKAMP, E.W.; BIJMA, P.; GROEN, AB.F.; VOS, H.; BOVENHUIS, H.; HARLIZIUS, B.; ARENDONK, J.A.M.:

Züchterische Aspekte der nachhaltigen Rinderproduktion, Arch. Tierz., Dummerstorf 43 (2000) Special Issue, 34-39

EMANUELSON, U.; PHILIPSSON, J.:

Studies on somatic cell counts in milk from Swedish dairy cows. II. Estimates of genetic parameters for monthly test-day results. Acta Agric. Scand 34 (1984), 45-57

EMANUELSON, U.; DANELL, B.; PHILIPSSON, J.:

Genetic parameters for clinical mastitis, somatic cell counts and milk production estimated by multipletrait restricted maximum likelihood. J. Dairy Sci., 71 (1988), 467-476

GULYAS, L.; IVANCSICS, J.

Zusammenhänge zwischen der somatischen Zellzahl und einigen eutermorphologischen Eigenschaften, Arch. Tierz., Dummerstorf 44 (2001), 15-22

MAIJALA, K.; HANNA, M.: 
Reliable phenotypic and genetic parameters in dairy cattle. Pro. $1^{\text {st }}$ World Congr. Genet. Appl. Livest. Prod. 1 (1974), 541

MILLER, R.H.; SCHULTZE, W.D.:

Genetic resistance to mastitis. Page 51 in Proc. Natl. Mastitis Counc. Annu. Mtg. 1981

MONARDES, H.G.; CUE, R.I.; HAYES, J.F.:

Correlations between udder traits and somatic cell count in Canadian Holstein cows. J. Dairy Sci. 73 (1989), 1337-1342

SCHAEFFER, L.R.:

Estimates of variance components for Holstein type traits. Can. J. Anim. Sci. 63 (1983), 763-772

SCHAEFFER, L. R.; VINSON, W.E.; PEARSON, R.E.; LONG, R.G.:

Genetic and phenotypic relationships among type traits scored linearly in Holsteins. J. Dairy Sci. 68 (1985), 2984-2989

SCHUTZ, M.M.; VANRADEN, P.M.:

Relationship of somatic cell score and linear type traits evaluations of Holstein sires. J. Dairy Sci. 76 (1993), 658-663

SEYKORA, A.J.:

Genetic parameters of udder and teat characteristics and their relationship to somatic cell count. J. Dairy Sci. 65 (1982),1280-1293

SEYKORA, A.J.; MCDANIEL, B.T.:

Genetic statistic and relationship of teat and udder traits, somatic cell count and milk production. J. Dairy Sci 69 (1986), 2395-2407

SMITH, S.P.; ALLAIRE, F.R.; AYLOR, W.R.; KAESER, H.E.: CONLY J.:

Genetic parameters and environmental factors associated with type traits scored on an ordered scale during the first lactation. J. Dairy Sci. 68 (1985), 2058-2066

THOMAS, C.L.; VINSON, W.E.; PEARSON, R.E.; DICKINSON, F.N.; JOHNSON, L.P.:

Relationships between linear type scores, objective type measures and indicators of mastitis. J. Dairy Sci. 67 (1984), 1281-1287

THOMPSON, J.R.; FREEMAN, A.E.; WILSON, D.J.; CHAPIN, C.A.; BERGER, P.J.; KUCK, A.: Evaluation of a linear type program in Holsteins. J. Dairy Sci. 64 (1981), 1610-1619

THOMPSON, J.R.; LEE, K.L.; FREEMAN, A.E.; JOHANSON, L.P.:

Evaluation of linearized type appraisal system for Holstein cattle. J. Dairy Sci. 66 (1983), 2025-2031

VAN VLECK, L.D.; HORMAN, H.D.:

Association of type traits with reasons for disposal. J. Dairy Sci. 55 (1972), 1698-1711

WEIGEL, D.J.; CASSELL, B.G.; PEARSON, R.E.:

Prediction of transmitting abilities for productive life and lifetime profitability from production, somatic cell count, and type traits in milk markets for fluid milk and cheese. J. Dairy Sci. 80 (1997), 1398-1405

WELLER, J.I.; SARAN, A.; ZELIGER, Y.:

Genetic and environmental relationships among somatic cell count, bacterial infection, and clinical mastitis. J. Dairy Sci. 75 (1992), 2531-2540

Received: 2001-02-26

Accepted: 2002-02-28

Corresponding Author

Dr. ASHRAF A. AMIN

Department of Animal Production, Faculty of Agriculture, Suez Canal University,

41522-Ismailia - Egypt

E-Mail: aamin@nt.suez.edu.eg 